\title{
Welding and Thermal Spray Processes for Maintenance of Hydraulic Turbine Runners: Case Studies
}

Rodolpho Fernando Váz ${ }^{1}$ (D), Romildo Tristante ${ }^{2}$, Anderson Geraldo Marenda Pukasiewicz ${ }^{3}$ (D), Andre Ricardo Capra ${ }^{4}$, André Chicoski ${ }^{4}$, Carlo Giuseppe Filippin ${ }^{4}$ (D), Ramón Sigifredo Cortés Paredes ${ }^{5}$ (D) , Sergio Luiz Henke ${ }^{5}$ (1)

${ }^{1}$ Centro de Proyección Térmica CPT, Universitad de Barcelona, Barcelona, España.

${ }^{2}$ Copel Geração e Transmissão S.A., Curitiba, PR, Brasil.

${ }^{3}$ Universidade Tecnológica Federal do Paraná - UTFPR, Ponta Grossa, PR, Brasil.

${ }^{4}$ Instituto de Tecnologia para o Desenvolvimento Lactec, Curitiba, PR, Brasil.

${ }^{5}$ Universidade Federal do Paraná - UFPR, Curitiba, PR, Brasil.

How to cite: Váz RF, Tristante R, Pukasiewicz AGM, Capra AR, Chicoski A, Filippin CG, et al. Welding and thermal spray processes for maintenance of hydraulic turbine runners: case studies. Soldagem \& Inspeção. 2021;26:e2540. https://doi.org/10.1590/0104-9224/ SI25.40

\begin{abstract}
Hydraulic runners are susceptible to failures by cracks or wear by erosion, corrosion, or cavitation. The modern runners are fabricated in carbon steel and martensitic stainless steel. Arc welding processes normally do the repair of eroded areas, or cracked parts. Each material or type of repair needs specific criteria, procedures, and precautions to guarantee their success and prevent future issues, like the recurrence of the cracks or reduction of the useful life of the runner by modifications of the original material. Wear-resistant coatings are applied by welding or by thermal spray processes, considering this last one has no metallurgical interaction with the material of the runner, keeping the original properties of the material. For several years the companies Copel GeT, Lactec, UTFPR, and UFPR collaborate on the study of different techniques, methods, and processes to repair hydraulic runners, this work aims to present a short compilation, and examples of some results obtained applied on real runners.
\end{abstract}

Key-words: Hydraulic runners; Coatings; Welding; Thermal spray; Maintenance; Cavitation; Cracks.

\section{Processos de Soldagem e Aspersão Térmica para Manutenção de Rotores Hidráulicos: Estudos de Casos}

\begin{abstract}
Resumo: Rotores de turbinas hidráulicas estão sujeitos a falhas ou trincas ou desgaste por cavitação. Atualmente, os rotores são fabricados em aço carbono ou aço inoxidável martensítico. Os reparos de regiões desgastadas ou trincadas são normalmente feitos por processos de soldagem a arco elétrico. Cada material de fabricação do rotor e/ou tipo de reparo necessita de procedimento específico, critérios de inspeção e aceitação adequados e precauções para garantir o sucesso do reparo, bem como prevenir futuras incidências precoces de falhas. Materiais de adição resistentes ao desgaste têm sido aplicados por soldagem ou aspersão térmica, sendo que essa última técnica não altera características metalúrgicas e propriedades mecânicas do material dos rotores. Por diversos anos, as empresas Copel GeT, Lactec, UTFPR e UFPR cooperam e tem colaborado com estudos de diferentes técnicas, metodologias de aplicação e processos de reparo de rotores hidráulicos. Este artigo objetiva apresentar uma breve compilação e exemplos de resultados obtidos nesses diferentes estudos aplicados a rotores reais.
\end{abstract}

Palavras-chave: Turbinas hidráulicas; Revestimentos; Soldagem; Aspersão térmica; Manutenção; Cavitação; Trincas.

\section{Introduction}

Hydropower is probably the oldest renewable energy resource, converting the energy contained in the water (rivers, lakes, waterfalls, etc.) in electricity. Dams, canals, pipes, and hydraulic turbines are parts of this type of power plant. The hydraulic turbine or runner converts the flow of water in rotation (mechanical energy), and the electric generator converts the rotation from the runner axis in electricity [1,2].

The Brazilian company Copel Geração e Transmissão S/A operates 18 hydropower plants, with dozens of runners, capable to generate from tenths to hundreds of MW. To keep all turbines operating properly, the Copel GeT has invested in the adequate repairs of the eroded or cracked runners, and in the development of new techniques, mainly in welding procedures and thermal spraying processes to minimize the wear and degradation of the runners. The R\&D projects have been done, mainly under the Brazilian Electricity Regulatory Agency (ANEEL), hiring and working in partnership with many institutions, highlighting Lactec, UFPR, and UTFPR. The team of researches of these companies has contributed with publications in the theme of development

Received: 27 Aug., 2020. Accepted: 27 Oct., 2020

E-mail: rvaz@cptub.eu (RFV)

This is an Open Access article distributed under the terms of the Creative Commons Attribution Non-Commercial License which permits unrestricted non-

commercial use, distribution, and reproduction in any medium provided the original work is properly cited. 
of welding and thermal spraying processes and materials, as with the evaluation of the coatings or welding joints regarding the cavitation, erosion, and fatigue resistance, corrosion, and other mechanical properties.

The maintenance activities in hydropowerplants demand a short chronogram for the activities, since the generation unit must back to the operation as fast as possible, and the runners repairs must to be done carefully, following the technical protocols and procedures to guarantee the repair successful. The areas or components damages commonly are located in places without easy access. The quality of the service depends on the operator's dexterity, such move the welding torch with both hands or control the hands force during a polish activity. An important character of the workers is the obedience to the Engineer technical instructions; such respect temperatures during the welding or change the welding strategy to increase the mechanical properties of the joint, for example. The use of robots in field repairs is not usual, since each repair demands specific movements and welders or operators dedicated to the service are essential.

\subsection{Hydraulic turbine runners}

The main types of runners are the radial or impulse turbine, named turbine Pelton, that has bucket-shaped blades - Figure 1a -, used for head of water greater than $200 \mathrm{~m}$. Or the reaction turbines, Francis, also classified as diagonal turbine, that has blades carefully designed to obtain the maximum efficiency, applied in $80 \%$ of the hydraulic turbines in operation - Figure $1 \mathrm{~b}$-; and Kaplan or propeller, also called axial turbine - Figure 1c-, designed for low-head applications such as slow running, lowland rivers [1,3,4].
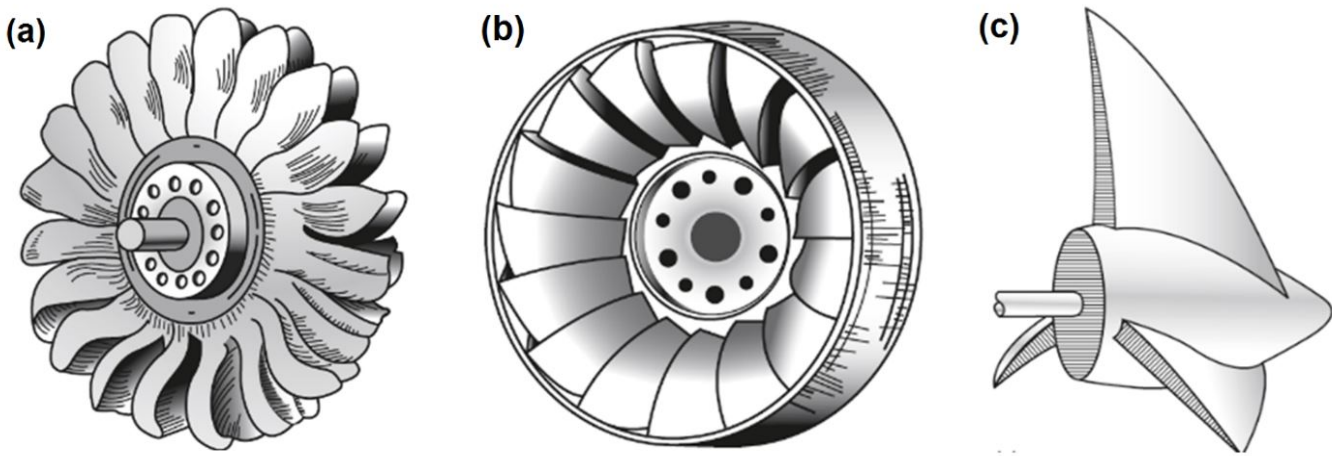

Figure 1. Types of runners normally used nowadays. (a) Pelton; (b) Francis; (c) Kaplan [1].

The runners are fabricated in different kinds of ferrous alloys, like cast iron, carbon steels, and stainless steels [1]. The development of runner objectives the maximum efficiency and the design is done for different parts (blades, crown, band, and others), which must be assembled [5]. The runner can be manufactured in one single casted section [6] or cast or forged in many parts, which are welded by arc electric processes, SMAW (Shielded Metal Arc Welding), ESW (Electroslag Welding), and specially GMAW (Gas Metal Arc Welding) and its variations [7,8].

Some materials have been widely used for the fabrication of runners. Highlights for low carbon steels and martensitic stainless steel, mainly the ASTM A743 grade CA6NM. The martensitic stainless steel for runners have been studied and applied for decades and is known the advantages of mechanical properties in comparison to the carbon steels, however, it is also known the susceptibility of the microstructural changes and decrease of toughness, after welding [9-12].

Some quality criteria of acceptance for welding or die-cast processes of fabrication must be considered. Porosity, cracks, deformations, and microstructural or mechanical inappropriate properties in the materials are examples of defects or discontinuities of casting $[6,13]$ or welding [14]. Normally, after the welding procedures, post heat treatments are applied for stress relief, the most common is the thermal treatment of tempering $[10,15]$, however, other processes were studied, such vibration during and after the welding [16]. After manufacturing the component needs to be inspected, some NDT (NonDestructive Testing) is used. The main NDT techniques are the ECT (Eddy Current Testing) and MPT (Magnetic Particle Testing), to detect and characterize surface and sub-surface flaws in conductive materials; DPT (Dye Penetrant Testing) or LPT (Liquid Penetrant Testing), to check surface-breaking defects on non-porous materials; UT (Ultrasonic Testing) and industrial radiography, which allow the detection of flaws deep in the part. However, to verify the mechanical properties of the weldments, a non-destructive hardness can be done, but some destructive testing is often needed, such Charpy testing, to measure the toughness; traction testing, to measure the mechanical resistance; fatigue testing, and many others.

\subsection{Defects and repairing of runners}

During the operation, runners are susceptible to unpredicted events and overloads, like the impact of unexpected objects, rocks, woods, and others; or can operate on the inadequate head of water, or other situation that promotes excessive vibration. These occurrences can reduce the life of the runner promoting premature failure or wear, such the cavitation erosion or 
nucleation and growth of cracks. For these reasons, is important and fundamental the periodic and effective maintenance inspection of vital parts of the turbines, in special the runners $[17,18]$.

It is imperative the repair of the cracked parts since the cracks always nucleate and follow the plane with the highest stress field. If the cracks are not monitored, measuring the crack growth rate, to decide the best moment to repair, a catastrophic failure can occur. Arc welding process, applying materials with similar properties to the base metal is the most used technique to repair cracks and worn areas. Basically, the repair consists of the elimination of the crack, removing the affected material, welding the parts, and recovering the hydraulic profile by machining $[18,19]$. After repair, a metallurgic inspection, to identify possible cracks is done by visual inspection and NDT, like DPT or MPT. By FEM (Finite Element Method) is possible to identify the regions of the runner susceptible to cracks and, by this preview, the inspection is focused on these areas.

The welding repair of cracks in CA6NM was studied with the intent to reduce the effect of the welding on the properties of the metal base. Behene and Paredes [20] evaluated how the parameter current in PTA (Plasma Transferred Arc) influenced the content of the phase ferrite-delta in the CA6NM welding material; with $200 \mathrm{~A}$, a volume of $5 \%$ of ferrite-delta was formed, while $10 \%$, with $160 \mathrm{~A}$. They also indicated the effectiveness of post-weld thermal treatment, reducing from $10 \%$ to $6 \%$ the ferrite-delta content, after the tempering at $600{ }^{\circ} \mathrm{C}$ for $1 \mathrm{~h}$. The high content of ferrite-delta reduces the toughness of the martensitic stainless steel [11] and the thermal treatments of solubilization and tempering are applied during the runner's fabrication process [10,15], however, this post treatment is not easily applied in maintenance of large runners [21], justifying studies to increase the toughness of the welded joint without post treatment processes. Gouveia et al. [22] indicated that the control of interpass temperature for GTAW (Gas Tungsten Arc Welding) is effective on the increment of impact toughness, from $128 \mathrm{~J}$, with interpass $150{ }^{\circ} \mathrm{C}$, to $165 \mathrm{~J}$, with interpass $80{ }^{\circ} \mathrm{C}$, values higher than the obtained for FCAW (Flux-Cores Arc Welding) process, between $25 \mathrm{~J}$ and $120 \mathrm{~J}$ [19]. The lower interpass temperature also improved the fatigue behavior of the joint, both in the welding materials and HAZ (Heat Affected Zone) [22].

Wear of the runners is other maintenance issue in hydropower plants, erosion occurs by solid particles impact, which causes mass loss of the runner, changes in hydraulic profile and reduction of efficiency [12]. Erosive wear of the turbine parts is a complex phenomenon that depends on properties and characteristics of the eroding particles, properties of the runner material, and operating conditions [23]. The deposition of erosion resistant coatings have been done around the world, mainly by thermal spraying process of WC alloys $[24,25]$. The damage by the cavitation phenomena is another situation that impairs the integrity of the runners. Many books, conference papers, and articles contribute to learn and understand the cavitation phenomena and its damage mechanisms. Cavitation phenomenon is related to the variation of velocity and pressure fields on the flow of the liquid, creating and imploding microbubbles [26,27]. The energy from the micro-jets from the implosion wears the material of the component $[28,29]$.

To improve the cavitation resistance, coatings have been applied to the susceptible areas of the runners by welding process, mainly GMAW and its variations, depositing materials more resistant than the original material of the runner. Co content filler metals have superior resistance [30,31], however, in the case of carbon steel runners, the deposition of stainless steel 309L already is a possible and effective solution, due to its higher resistance to cavitation [12]. Will et al. [30] evaluated the cavitation resistance of 309LSi and Co-steel alloys coatings welded by PTA with different parameters of the pulsed current, resulting in the lowest erosion rate for the Cavitec alloy, $0.45 \mathrm{mg} / \mathrm{h}$, welded with pulsed current 180/120 A and peak/base time $0.1 / 0.1 \mathrm{~s}$. By the same process, but with current $160 \mathrm{~A}$, da Cruz, Henke, and d'Oliveira [32] welded the FeMnCrSi alloy [33], obtaining erosion rate of $0.52 \mathrm{mg} / \mathrm{h}$, aswelded, and $0.33 \mathrm{mg} / \mathrm{h}$, after mechanical cold work post-treatment, which converted partially the phase austenite on martensite, increasing the hardness and cavitation resistance. Using the same PTA pulsed arc process, but with pulsed current 180/80 A and peak/base time $0.1 / 0.1 \mathrm{~s}$, Pukasiewicz et al. [34] remelted FeMnCrSi [33] alloy arc-sprayed coatings, reaching the erosion rate of $0.65 \mathrm{mg} / \mathrm{h}$. An important consideration in this theme is that all of the experiments were better than the base metal reference, CA6NM, which had an erosion rate of $6.7 \mathrm{mg} / \mathrm{h} \mathrm{[34].}$

In the thermal spraying field of study, were studied different processes and variations of parameters focusing on the improving of runner's cavitation resistance. Lamana, Pukasiewicz, and Sampath [24] studied the mechanism of cavitation by the detachment of WC particles sprayed by HVOF (High-Velocity Oxy-Fuel) with kerosene and propylene fuels. Sucharski et al. [35] optimized the HVOF parameters standoff distance, powder feed rate, and carrier gas pressure to improve the properties of FeMnCrSiNi alloys [33], reaching the porosity $0.05 \%$, oxide content $8.94 \%$, tensile adhesion $40.29 \mathrm{MPa}$, and microhardness 366 HV. With the same alloys, Silveira et al. [36] indicated the influence of the feedstock powder size distribution on the cavitation resistance, reaching an erosion rate of $7.8 \mathrm{mg} / \mathrm{h}$ with powders $-45 \mu \mathrm{m}$. The compressive residual stress of $205 \mathrm{MPa}$ was seen on FeMnCrSi HVOF sprayed, which is related to the improvement of the cavitation resistance $19.1 \mathrm{mg} / \mathrm{h}$ [37]. Vaz et al. [38], using the ASP (Arc Spraying Process), indicated the best standoff distance for FeMnCrSi [33], reaching the highest Kinetic Energy for the particles in flight at $200 \mathrm{~mm}$, with velocity $150 \mathrm{~m} / \mathrm{s}$. Mayer et al. [39] indicated the synergism between corrosion/cavitation $\mathrm{Cr}_{3} \mathrm{C}_{2}-\mathrm{NiCr}$ alloys, with higher mass loss by cavitation on $\mathrm{NaCl}$ solution than on deionized water.

\section{Case Studies}

\subsection{Carbon steel crack, UHEGNB}

The hydropower plant Governador Ney Aminthas de Barros Braga - UHEGNB - (Mangueirinha, PR, Brazil) have four large Francis type runners (135 ton and $315 \mathrm{MW}$ each), which are fabricated in one part only in carbon steel by die casting process by 
Hitachi (Tokyo, Japan), and there is not welding between the blades and the crown or the blades and the ring. During an inspection, a $30 \mathrm{~mm}$ length crack was revealed in the transition from a blade to the crown.

\subsubsection{Procedure}

For the crack repair of the runner, the procedure was:

- Identification of the crack length by visual inspection and DPT (Metal Chek, Bragança Paulista, SP, Brazil);

- Complete elimination of the affected area by manual grinding and preparing the chamfer for welding;

- Welding manually by GTAW (Miller XMT 304 CC/CV, Appleton, WI, USA), direct current 140 to180 A, using shielding gas Ar, with austenitic stainless steel filler metal AWS A5.9 309L diameter $3.2 \mathrm{~mm}$ (Welding Alloys). The preheating and interpass temperature was $120^{\circ} \mathrm{C}$;

- $\quad$ Grinding and polishing to adequate the profile of the surface;

- Visual inspection and DPT to evaluate the quality of the repair.

\subsubsection{Results}

The initial inspection resulted in the crack indicated in Figure $2 b$, which was located in the transition from the blade to the crown, as indicated in Figure 2a. During the elimination of the crack, some discontinuities from the casting fabrication process were found, Figure $2 \mathrm{c}$, and eliminated before the repairing welding, since they were in a region of high tension and they act as tension amplifiers.

After many welding beads, the aspect of as-welded repair is indicated in Figure $2 \mathrm{~d}$ and after the manual grinding and polishing procedure, the surface with adequate profile is presented in Figure 2e, which indicates also the result of the DPT, that did not revealed any discontinuity and from this interpretation the repair is approved. After about $20,000 \mathrm{~h}$ or 4 years operating, the visual inspection and the DPT of this area did not reveal a re-incidence of the crack, guaranteeing the quality of the repair.

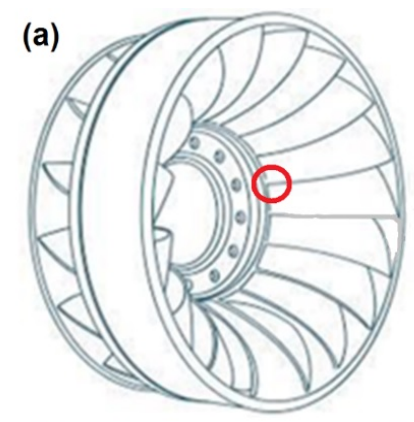

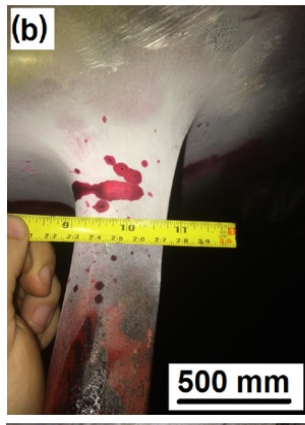

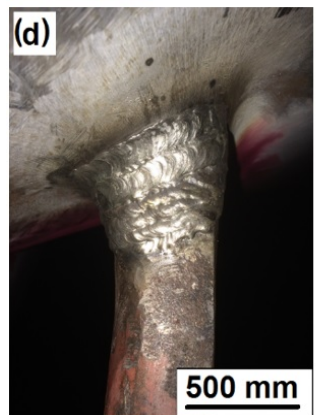

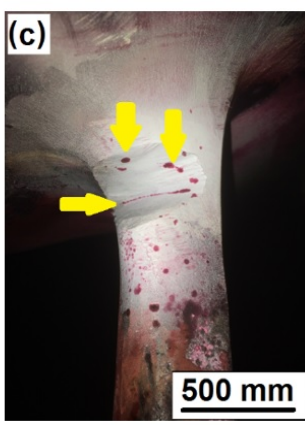

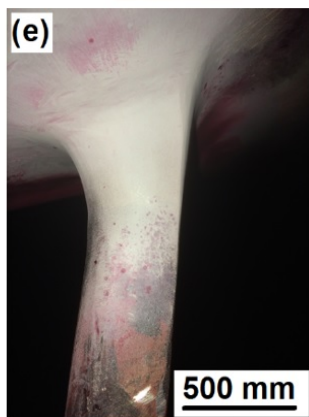

Figure 2. Crack repair of UHEGNB runner. (a) crack localization; (b) initial condition with cracked revealed by DPT; (c) crack and casting discontinuities observed during the grinding; (d) as-welded aspect; and (e) final aspect clear od discontinuities revealed by DPT. 


\subsection{Stainless steel runner crack, UHEGPS}

The hydropower plant Governador Pedro Viriato Parigot de Souza - UHEGPS - (Antonina, PR, Brazil) has four Pelton type runners (6.7 ton $65 \mathrm{MW}$ each) manufactured in ASTM A743 grade CA6NM stainless steel. Historically, its runners does not present many problems of cavitation or crack propagation. However, in an inspection, a $120 \mathrm{~mm}$ length crack was identified in a blade.

The runners manufactured in CA6NM are heat-treated for solubilization and tempering, in order to obtain a refinement of microstructure, reducing the amount of retained austenite, and stress relief $[10,24,34,40]$. Although, the welding repairs normally are not exposed to this post-treatment, mainly because of the difficulties to remove a big runner to a furnace or control the temperatures to do this in situ.

Some studies have focused on evaluate different techniques to relieve the impacts of welding on the heat affected zone of CA6NM steel. Selection of process with lower thermal input (GTAW, PTA, etc.), control of low temperature of inter-passes, and the use of tempering bead are some results relevant to minimize the reduction of toughness of base metal [9,11,17$20,34,41,42]$

\subsubsection{Procedure}

The procedure to repair the runner of UHEGPS followed the stages:

- Identification and delimitation of the crack length;

- Elimination of the crack, adjusts of the chamfer to the welding and confirmation of inexistence of crack or other discontinuities by DPT (Metal Chek, Bragança Paulista, SP, Brazil);

- Welding by manual GTAW (Miller XMT 304 CC/CV, Appleton, WI, USA), direct current 100 to140 A, using shielding gas Ar, with filler metal AWS A5.9 E410NiMo (Welding Alloys) diameter $3.2 \mathrm{~mm}$. The temperature of preheating was $120^{\circ} \mathrm{C}$ and interpasses was maintained between 80 and $100^{\circ} \mathrm{C}$. And two more passes above the surface of the base metal were done (tempering passes [34]);

- $\quad$ Restoring of blade profile by manual grinding and polishing. Measuring the roughness with equipment Mitutoyo SJ-210 (Kawasaki, Japan);

- Measure of the Hardness of the repaired area, using portable equipment Proceq Equotip 3 (Schwerzenbach, Switzerland);

- Visual inspection and DPT.

The analysis of the crack surface was done by Scanning Electron Microscopy (SEM) in equipment Tescan Vega 3 (Brno, Czech Republic).

\subsubsection{Results}

The crack was located in a region of high stress of the bucket, as indicated in Figure 3a, for the intern or pressure side or pressure of the bucket, and Figure 3b, for the back or suction side of the bucket. In Figure $3 b$ is delimited and area eroded by cavitation and indicated by arrow where the crack nucleated, from where was cut a piece for analysis by microscopy at the Lactec facilities (Curitiba, PR, Brazil).

The delimitation or identification of the original crack length was revealed by DPT, as presented in Figure 3c,d, while the elimination of the crack resulted in the chamfer indicated in Figure $3 e, f$, with the inexistence of discontinuities revealed by DPT. The final result after polishing to the roughness lower than Ra $1.0 \mu \mathrm{m}$ is presented in Figure 3g,h, with the positive result of DPT. The lowest possible roughness is important to prevent cavitation on hydraulic runners, since clear relation between the surface state and the cavitation phenomena was previously observed, and the lower is the roughness the lower is the cavitation erosion [43].

After finished the process, the hardness of the repaired area was measured, and the results were satisfactory and adequate. The base metal CA6NM before the welding had $247 \pm 8 \mathrm{HV}$, lower than the reference values for this material $290 \mathrm{HV}$ [19], $284 \mathrm{HV}$ [12], or $271 \mathrm{HV}$ [44]. The welding metal had 320 $\pm 30 \mathrm{HV}$, lower than references values $380 \mathrm{HV}$ [19], or

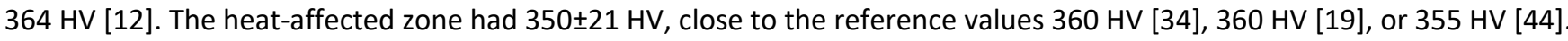

Analyzing the hardness of the material and its correlation to the toughness, the repair was considered done with success. However, the problems on the microstructure inherent to this process of repair cannot be easily quantified in-situ, mainly the content of the phase $\gamma$-austenite and $\delta$-ferrite in the $\alpha^{\prime}$-martensite of the CA6NM. Above determined amount of those phases, a reduction of the toughness of the material is seen $[11,20,24,40]$. In addition, the residual stress imposed on the component by the welding repair must be considered as an important factor for new crack nucleation. For those reasons, after few months operating, an inspection of the repaired parts was carefully performed and did not reveal any re-incidence of the crack in this bucket, confirming the success of the repair.

Figure 3i presents an image obtained by SEM. The crack had its nucleation in craters of the erosion by cavitation. This eroded area is seen on the suction face of the bucket in Figure $3 b$, and is located in a part of the bucket with a high concentration of stress due to the operation principles [45]. 

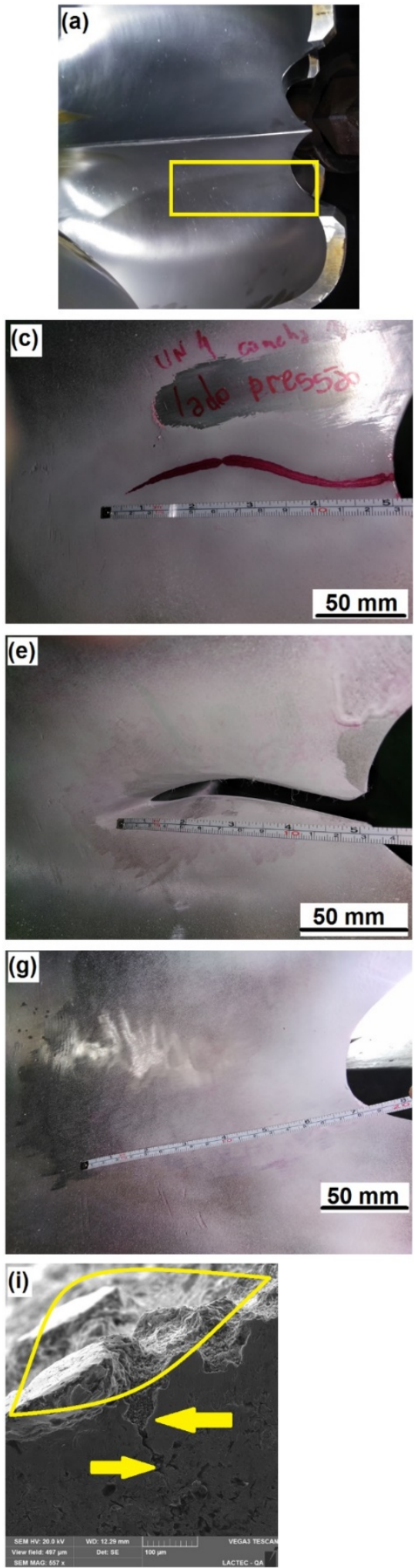
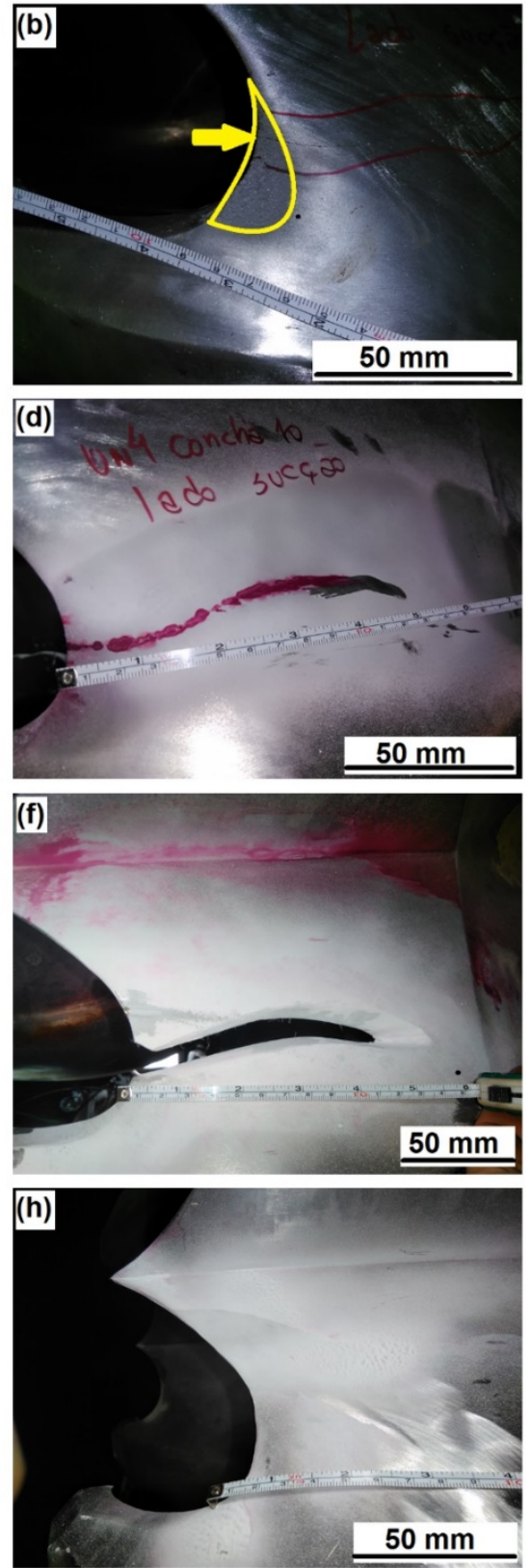

Figure 3. Crack repair of UHEGPS runner. $(a, b)$ crack localization, pressure and suction bucket sides; $(c, d)$ crack revealed by DPT, pressure and suction bucket sides $(e, f)$ chamfer prepared to welding and total elimination of crack revealed by DPT, pressure and suction bucket sides; $(g, h)$ final aspect of repaired area, after revelation of DPT, pressure and suction bucket sides, and (i) SEM image of crack surface, circled the eroded area and indicated by arrows a crack.

\subsection{Carbon steel runner eroded by cavitation, UHEGBM}

The hydropower plant Governador Bento Munhoz da Rocha Netto - UHEGBM - (Pinhão, PR, Brazil) have four large Francis type runners ( 113 ton and $420 \mathrm{MW}$ each) originally fabricated in carbon steel ASTM A27, with some parts coated with stainless 
steel. However, many repairs have been made since the start of operation in the 1980's. Some repairs of cavitation reached more than a thousand of $\mathrm{kg}$ of welded material, but this amount was reduced in the last years due the use of more actual repair procedures, mainly with more control of the welding parameters, such the GMAW pulsed-arc, which promotes more microstructure refinement, better mechanical, and higher fatigue resistance [46], what is important, since the cavitation resistance is linked to the material fatigue resistance.

Depositions of some cavitation resistant special alloys, like Cavitaloy, Cavitec, or Hydroloy using SMAW and GMAW had been done and the reduction of the erosion was effective. These alloys have higher resistance to cavitation due to their content of Co (close to $11 \mathrm{wt} . \%$ ) and absorption of energy from the cavitation without mass loss [12,31]. The deposition of these alloys is up to $10 \mathrm{~mm}$ thick only, on the $309 \mathrm{~L}$ austenitic stainless steel cushion layers.

Other activity done on UHEGBM runners was the deposition of coatings by ASP thermal spraying. The FeMnCrSi alloys sprayed were results of R\&D project and are under patent [33]. These alloys as-sprayed and as remelted by PTA presented resistance to cavitation very close to alloys with Co $[34,47,48]$, justifying their use.

\subsubsection{Procedure for welding repair}

The procedure of repair followed the stages:

- Delimitation of the eroded areas done visually by an expert inspector, who defined the areas to be repaired;

- $\quad$ Elimination of eroded material by arc gouging and by grinding. Inspection of the area cleaned by visual inspection and DPT (Metal Chek, Bragança Paulista, SP, Brazil);

- Welding by GMAW (Miller XMT $304 \mathrm{CC} / \mathrm{CV}$, Appleton, WI, USA), inverse current $140 \mathrm{~A}$, using shielding gas $\mathrm{Ar}+25 \% \mathrm{CO}_{2}$, depositing layers of AWS A5.18 ER70S-6 (Esab), AWS A5.9 E309LT1 (Welding Alloys). Other layers by GMAW (MTE Digitec 450 (Florianópolis, SC, Brazil), inverse pulsed-current, peak/base current 200/100 A, peak/base time $0.5 \mathrm{~s}$, using shielding gas $\mathrm{Ar}+8 \% \mathrm{O}_{2}$, depositing Cavitaloy (Welding Alloys), following the indicated in Figure 4. If the metal base prepared is not carbon steel, the use of the ER70S-6 layer must not be applied;

- $\quad$ Restoration of blade profile by manual grinding and polishing, resulting in smooth surface. To evaluate the roughness, a Mitutoyo SJ-210 (Kawasaki, Japan) was used;

- $\quad$ Final inspection of integrity by DPT, revealing the inexistence of discontinuities.

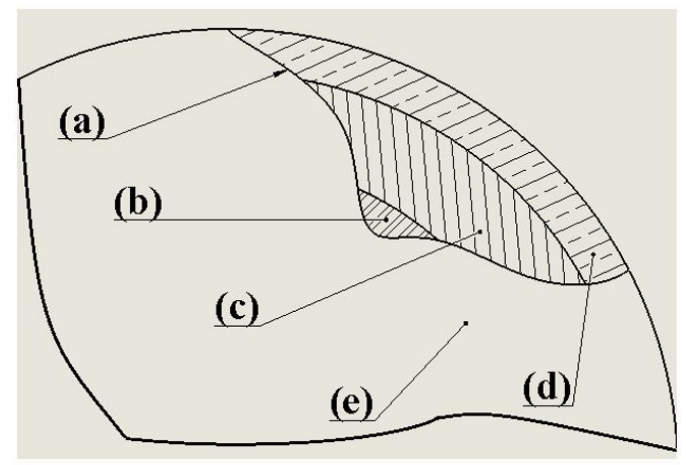

Figure 4. Scheme of repair of eroded area, depositing Co alloys. (a) prepared area after elimination of worn material; (b) carbon steel welding; (c) 309L welding, thickness between 9 and $15 \mathrm{~mm}$; (d) Cavitaloy, thickness up to $10 \mathrm{~mm}$; (e) base metal of the runner.

\subsubsection{Results for welding repair}

The area indicated in Figure 5a presented the most severe wear in the UHEGBM runner, with the erosion of the stainless steel coating, Figure $5 b(3)$, reaching the carbon steel metal base Figure $5 b(2)$, and even passing through the blade Figure $5 b$ (1). The unharmed area of the runner is indicated by (4) in Figure 5b. Similar condition was seen in all of the 15 blades of the runner.

After the total elimination of the eroded material and preparation of the surface for the welding, the visual inspection and DPT did not indicate discontinuities and the welding was done, following the steps indicated in Figure 4, with the as-weld aspect presented in Figure $5 \mathrm{c}$. The welding beads are in horizontal direction with the objective to reduce the residual stress in the region of the transition from the blade to the runner external ring.

The result of the manual adjustment of the profile and final inspection by DPT is indicated in Figure $5 \mathrm{~d}$, with no discontinuities seen. The manual polishing resulted in a roughness of Ra $1.2 \pm 0.4 \mu \mathrm{m}$, under the roughness of the unharmed blade areas, which helps to prevent the cavitation phenomena [43]. 

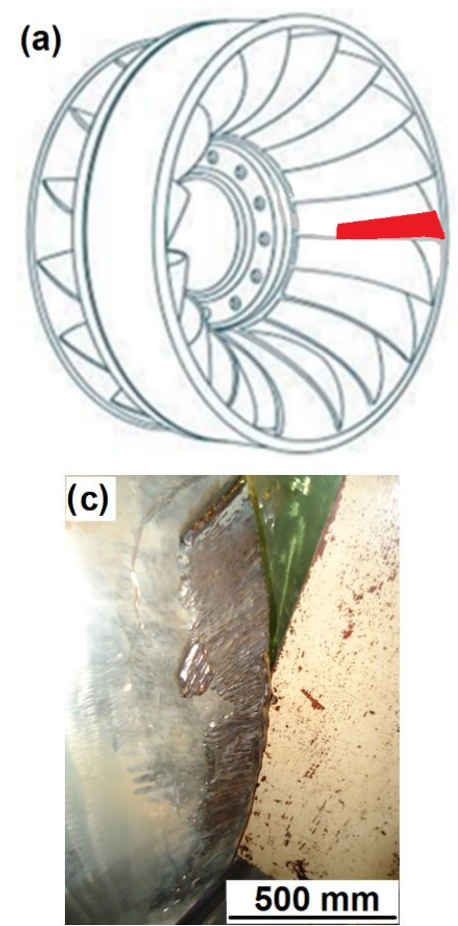
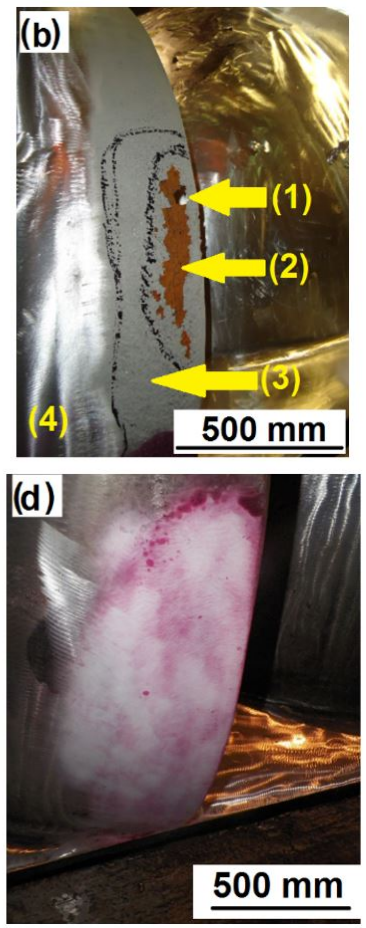

Figure 5. Erosion repair of UHEGBM runner. Stages of repair: (a) region eroded; (b) mapping of damage; (c) welding beads; and (d) revelation of DPT after restoration of blade profile.

\subsubsection{Procedure for thermal spray repair}

The procedure followed the stages:

- $\quad$ Delimitate the area for ASP deposition;

- $\quad$ Cleaning and adapting the roughness of the surface, by manual grit blasting with alumina;

- $\quad$ Deposition of the coating by manual ASP, using equipment Sulzer Metco 300E (Westburry, NY, USA), with optimized parameters: Voltage $30 \mathrm{~V}$, current $180 \mathrm{~A}$, standoff distance $200 \mathrm{~mm}$, speed $4 \mathrm{~m} / \mathrm{min}$, 5 layers;

- $\quad$ For the areas without PTA remelting, manual polishing;

- $\quad$ For the areas with the PTA pulsed arc remelting, the installation of the welding equipment, MTE Digitec 450 (Florianópolis, SC, Brazil), and robot, Bug'O Systems (Canonsburg, PA, USA) to remelting with optimized parameters, Table 1.

- $\quad$ After all, manual polishing.

Table 1. Parameters of PTA remelting.

\begin{tabular}{cc}
\hline Parameter & Value \\
Torch speed & $100 \mathrm{~mm} / \mathrm{min}$ \\
Standoff distance & $10 \mathrm{~mm}$ \\
Gas of plasma flow (Ar) & $1.5 \mathrm{~L} / \mathrm{min}$ \\
Protection gas flow (Ar) & $12.0 \mathrm{~L} / \mathrm{min}$ \\
Interpass temperature & $80^{\circ} \mathrm{C}$ \\
Current & $130 / 160 \mathrm{~A}$ \\
Peak / base time & $0.1 / 0.1 \mathrm{~s}$ \\
\hline
\end{tabular}

\subsubsection{Results for thermal spray repair}

This thermal sprayed coating had not the objective to recover deep eroded areas of the runner, but insert a layer about $300 \mu \mathrm{m}$ thick on areas of the blade with lighter cavitation. In this way, the selected area to be coated was the neighborhood of the welded recover, to protect the region where the cavitation/corrosion occurs due to the galvanic pair formed in the interface carbon steel/stainless steel. The synergy cavitation/corrosion is presented by Mayer et al. [39], interpreting the effective influence of the corrosion on the cavitation behavior of the material. However, for the remelted coatings, the same region of the severe cavitation erosion was selected, since the alloys FeMnCrSi in the condition of welded presented resistance close to the welded Co alloys $[34,47,48]$ and had higher corrosion resistance than the substrates [49]. 
Figure $6 a$ indicates the activity of manual deposition of the coating on the previously prepared surface by manual sand-blasting, which cleaned the surface to grade Sa3 and rough to a minimum Ra $5.0 \mu \mathrm{m}$ and Ry $30 \mu \mathrm{m}$. The as-sprayed characteristic is indicated by the arrows in Figure $6 \mathrm{~b}$, and as-polished by the circle in Figure $6 \mathrm{c}$, with roughness lower than Ra $1.0 \mu \mathrm{m}$. The remelting torch and robot are presented in Figure $6 \mathrm{~d}$, the as-welded aspect indicated by arrows in Figure $6 \mathrm{e}$, and the polished condition in Figure $6 \mathrm{f}$.

Inspections of this runner, after thousands of hours of operation, indicated the rate of volume loss by cavitation on this remelted area similar to observed on Co-steel welded areas, and lower than $309 \mathrm{~L}$ welded, proving the efficiency of the application of the FeMnCrSi alloys by ASP and PTA remelted.
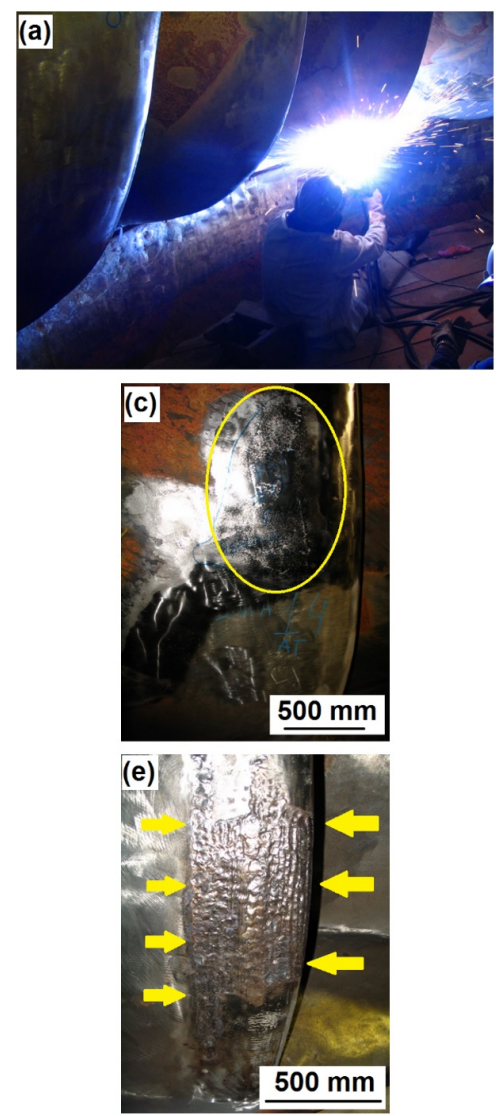
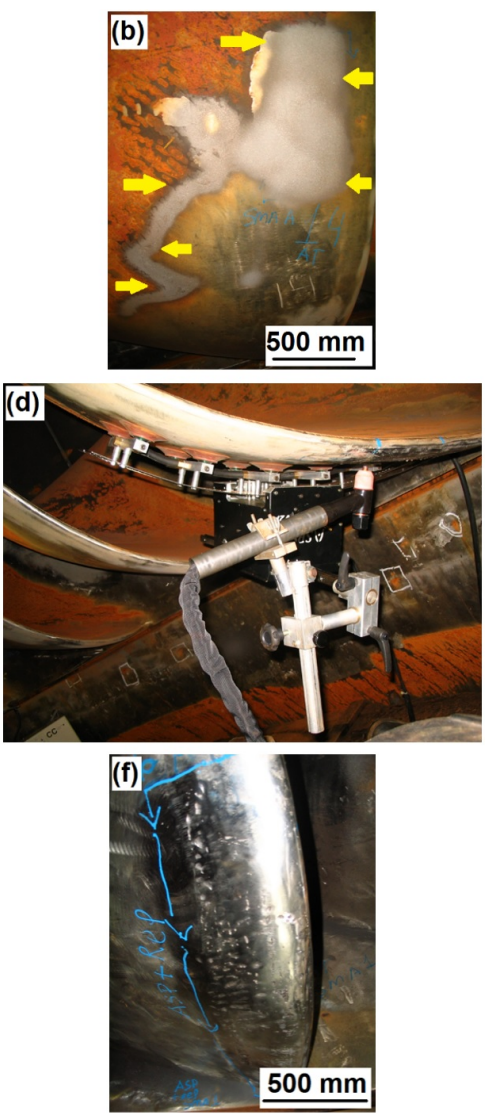

Figure 6. Coating by ASP of UHEGBM runner. (a) deposition of coating; (b) as-sprayed aspect (coating indicated by arrows); (c) polish aspect (area circled); (d) PTA torch prepared for remelting; (e) remelted aspect (area indicated by arrows); (f) polish aspect.

\subsection{Stainless steel runner eroded by cavitation, UHEGJR}

The hydropower plant Governador Jose Richa - UHEGJR - (Capitão Leonidas Marques, PR, Brazil) have four Francis type large runners (160 ton and $315 \mathrm{MW}$ each) manufactured in CA6NM. Historically, the runners of UHEGJR presented very low mass loss by cavitation and the manual polishing of the surfaces is made as to the repair procedure of the component. This polishing is enough to reduce the rate of mass loss by erosion since the roughness degrease changes the flow of the water in these specific areas and reduces the cavitation phenomena $[43,50]$.

The objective of the researchers, depositing the FeMnCrSi coatings by ASP on the runners, was to save the CA6NM from the erosion and postpone or retard for the maximum possible the welding for erosion repairing.

\subsubsection{Procedure}

The repair procedure of the runner of UHEGJR followed the stages:

- Visual inspection, identification and delimitation of the eroded area. Erosion deeper than 1 mm was coated by thermal spray, but the shallower areas were just polished;

- $\quad$ By manual grinding, done the elimination of the eroded material and adjusts of the surface for the grit blasting, which was done manually with alumina on larger area than the sequence coated area;

- Deposition of the FeMnCrSi alloy coating by manual ASP, using equipment Metallisation ARC 140/S350-CL, with gun Metallisation ARC-CG16 (Dudley, United Kingdom). The parameters adopted were $30 \mathrm{~V}, 180 \mathrm{~A}$, and standoff $200 \mathrm{~mm}$; 
- $\quad$ After all, manual polishing and measuring of the roughness using equipment Mitutoyo SJ-210 (Kawasaki, Japan).

During this deposition, some couples were prepared with exactly the same conditions than the runner substrate. The samples were prepared in accordance with ASTM E1920-03 and the images were obtained by optical microscopy in equipment Olympus BX51M (Tokyo, Japan) and the micro hardness of the transversal section measured in equipment Emco-Test Durascan 20 (Kuchl, Austria).

\subsubsection{Results}

The area delimited to be coated, on the ring and close to the blades, is schematically indicated for one area in Figure 7a. The initial condition is indicated in Figure $7 \mathrm{~b}$, considering that this condition is repeated for almost all of the blades. The manual deposition, Figure 7c, resulted in a dark gray coating, Figure 7d, which became very bright after polishing to a roughness lower than Ra $1.0 \mu \mathrm{m}$, Figure 7e.

After 20,000 h of operation, the inspection of the runner indicated the effectiveness of the sacrificial FeMnCrSi coating, which was eroded to prevent the wear of the CA6NM, as indicated by arrows in Figure 7f. On this surface was again sprayed the coating, but an inspection with less time of operation is desirable to measure the rate of volume loss of the coating and determine the interval time for re-deposition of the coating more sharply.

From the microscopy of a sample cross-section, the Figure $7 f$ was obtained, from where is possible to see the typical morphology of the ASP coatings, with metallic phase, oxide layers, and vacancies or porous. From the image analysis was interpreted a porosity lower than $2 \%$, which is in accordance with the presented by other researches [34,51,52]. The low amount of porosity is important, because it has a severe influence on the cavitation resistance since the mechanism of mass loss by cavitation is related to the lower adhesion between the metallic lamellae in the coating [36]. The higher porosity the lower cohesion in the coatings $[39,53]$. The microhardness of the coatings, measured in the transversal section was $312 \pm 16 \mathrm{HV} 0.3$, which is consonant to the obtained by Pukasiewicz et al. [34,47], confirming the replication of the laboratory properties on the in-situ application properties.
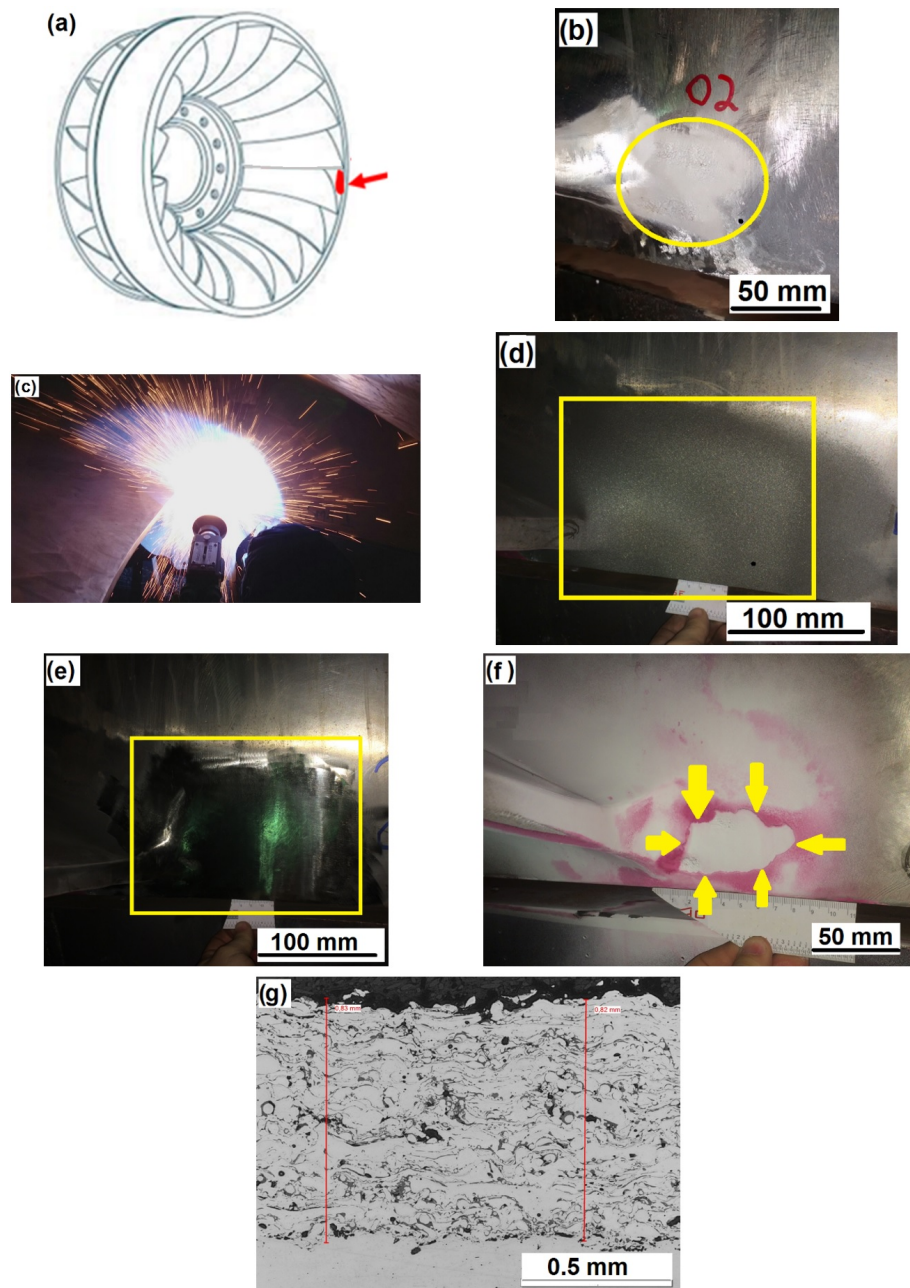

Figure 7. UHEGJR runner eroded by cavitation. (a) Eroded area delimitation; (b) eroded surface; (c) manual deposition of the coating by ASP

(d) as-sprayed coating; (e) polished coatings; ( $\mathrm{f}$ ) revelation of DPT on the same area after 20,000 $\mathrm{h}$ of operation of the turbine; and ( $\mathrm{g}$ ) morphology of the coatings by optical microscopy. 


\section{Conclusion}

The damages in the runners are a constant in the operation of hydropower plants, independent on the size, capacity, type of runner, or material of fabrication. The erosion and cracks for different reasons will continue occurring in the future and the $R \& D$ projects and specialized services can contribute to do repairs with minimal interference or changes on the integrity of the material of runners.

The use of new technologies, adequate selection, and control of welding parameters, respect to the procedure, and development of new dedicated materials are results of the research activities and its use on repairs of runners has become useful to promote long life to the runners and less time for repairs. The use of results of researches on the effective repair of runners prevented premature or catastrophic failures, as guaranteed the predicted life of the runners.

The use of GTAW with controlled parameters and low interpass temperature was a success on the crack repairing of the UHEGPS runner, without recurrence of the crack in this bucket after many hours of operation. The use of Co-alloy by GMAW pulsed current reduced the cavitation erosion on the blades of the UHEGBM runner. The application of FeMnCrSi alloys by thermal spraying retarded the use of welding on the CA6NM UHEGJR runners, and the post-treatment of PTA remelting on the FeMnCrSi arc-sprayed presented results close to the welded Co-steel. These and many others results encourage the team of researchers to keep studying and looking for new developments in the field of maintenance and repairing of hydraulic runners.

\section{Acknowledgements}

The authors thank Copel GeT, for financial support to the R\&D projects and for the access to the repair services reports; Lactec, for the execution of R\&D projects and repair services; UFPR and UTFPR, for access to the equipment and laboratories for analysis and tests; Brazilian Electricity Regulatory Agency ANEEL, for the regulation of R\&D projects; Brazilian National Council for Scientific and Technological Development CNPq, for fiscal incentives to import equipment to Brazil.

Rodolpho F. Váz also thanks very much all the welders and workers involved in any of the services, in special Mr. Sebastião Lemos, for the engaging and respect to the procedures of services.

\section{References}

[1] Breeze P. Power generation technologies. Oxford: Newnes; 2005.

[2] Schreiber GP. Usinas hidrelétricas. Sao Paulo: Edgard Blucher; 1978.

[3] Krivchenko GI. Hydraulic machines: turbines and pumps. 2nd ed. Boca Raton: Lewis Publishers; 1994.

[4] Turkon RK. General concepts of hydraulic turbine construction. In: Zu-yan M, editor. Mechanical design and manufacture of hydraulic machinery. New York: Routledge; 1991. p. 1-6.

[5] Ayancik F, Aradag U, Ozkaya E, Celebioglu K, Unver O, Aradag S. Hydroturbine runner design and manufacturing. International Journal of Materials, Mechanics and Manufacturing. 2013;1(2):162-165. http://dx.doi.org/10.7763/IJMMM.2013.V1.35.

[6] Jinwu K, Tianyou H, Baicheng L. Review of production status of heavy steel castings and key technologies for their manufacture in China. China Foundry. 2008;5(1):1-6.

[7] Tonooka H, Okuni T, Ito H, Kawano M, Jimbo T, Fukasu S. Welded Francis type runner. US Patent 3,797.965. 1974 Mar 19.

[8] Kawano M, Ito H, Jimbo T, Tonooka H, Okuni T, Fukasu S. Method of manufacturing a welded type Francis runner. US Patent 3,918,627. 1975 Nov 11.

[9] Henke SL, Niño CE, Buschinelli AJA, Corrêa JA. Especificação de procedimentos de reparo por soldagem de aços inoxidáveis martensíticos macios sem tratamento térmico posterior. In: Anais do XXIV Encontro Nacional de Tecnologia da Soldagem; 1998; Fortaleza. São Paulo: ABS; 1998. p. 1-11.

[10] Tavares SSM, Rodrigues CR, Pardal JM, Barbosa ES, Abreu HFG. Effects of post weld heat treatments on the microstructure and mechanical properties of dissimilar weld of supermartensític stainless steel. Materials Research. 2014;17(5):1336-1343. http://dx.doi.org/10.1590/1516-1439.299314.

[11] Carrouge D, Bhadeshia HKDH, Woollin P. Effect of $\delta$-ferrite on impact properties of supermartensitic stainless steel heat affected zones. Science and Technology of Welding and Joining. 2004;9(5):377-389. http://dx.doi.org/10.1179/136217104225021823.

[12] Santa JF, Blanco JA, Giraldo JE, Toro A. Cavitation erosion of martensitic and austenitic stainless steel welded coatings. Wear. 2011;271(9-10):1445-1453. http://dx.doi.org/10.1016/j.wear.2010.12.081.

[13] Morrow FA, Alcini MJ, Kiiskila FL, Lewis C, Gavin W, Brozo F, et al. Testing and inspection of casting defects. In: ASM International. ASM handbook. Vol. 15. Materials Park: ASM International; 1992. p. 1175-1205.

[14] American Welding Society - AWS. AWS B1.10: guide for nondestructive inspection of welds. Miami: AWS; 1985. 
[15] Gesnouin C, Hazarabedian A, Bruzzoni P, Ovejero-García J, Bilmes P, Llorente C. Effect of post-weld heat treatment on the microstructure and hydrogen permeation of 13CrNiMo steels. Corrosion Science. 2004;46(7):1633-1647. http://dx.doi.org/10.1016/j.corsci.2003.10.006.

[16] Almeida LFCB, Lourenco JC, Faria MIST, Vieira DL, Robin ALM, Nunes CA. Vibratory stress relief and vibratory weld conditioning of flux cored arc welded CA6NM steel. Journal of Materials Science Research. 2019;9(2):32-41. http://dx.doi.org/10.5539/jmsr.v9n1p32.

[17] Luna-Ramírez A, Campos-Amezcua A, Dorantes-Gómez O, Mazur-Czerwiec Z, Muñoz-Quezada R. Failure analysis of runner blades in a Francis hydraulic turbine: case study. Engineering Failure Analysis. 2016;59:314-325. http://dx.doi.org/10.1016/j.engfailanal.2015.10.020.

[18] Panthee A, Thapa B, Neopane HP. Quality control in welding repair of Pelton runner. Renewable Energy. 2015;79(1):96-102 http://dx.doi.org/10.1016/j.renene.2014.10.042.

[19] Silva RP, Faria MIST, Almeida LFCB, Nunes CA, Vieira D, Borges Jr W. Microstructure and mechanical properties of ASTM A743 CA6NM steel welded by FCAW process. Materials Research. 2017;20(6):1622-1629. http://dx.doi.org/10.1590/1980-5373-mr-2017-0468.

[20] Behene L, Paredes RSC. Formação de ferrita delta na soldagem de aço inoxidável super martensítico tipo CA6NM pelo processo plasma PTA. Soldagem e Inspeção. 2017;22(3):320-332. http://dx.doi.org/10.1590/0104-9224/si2203.09.

[21] Henke SL, Paredes RSC, Capra AR. Development of delta ferrite on the weld and HAZ produced by pulsed plasma arc welding on a supermartensitic stainless steel. Welding International. 2015;29(4):285-290. http://dx.doi.org/10.1080/09507116.2014.932977.

[22] Gouveia RR, Pukasiewicz AGM, Capra AR, Henke SL, Okimoto PC. Effect of interpass temperature on microstructure, impact toughness and fatigue crack propagation in joints welded using the GTAW process on steel ASTM A743-CA6NM. Welding International. 2015;29(6):433-440. http://dx.doi.org/10.1080/09507116.2014.932983.

[23] Padhy MK, Saini RP. A review on silt erosion in hydro turbines. Renewable \& Sustainable Energy Reviews. 2008;12(7):1974-1987. http://dx.doi.org/10.1016/j.rser.2007.01.025.

[24] Lamana MS, Pukasiewicz AGM, Sampath S. Influence of cobalt content and HVOF deposition process on the cavitation erosion resistance of WC-Co coatings. Wear. 2018;398-399:209-219. http://dx.doi.org/10.1016/j.wear.2017.12.009.

[25] Kumar H, Chittosiya C, Shukla VN. HVOF Sprayed WC based cermet coating for mitigation of cavitation, erosion \& abrasion in hydro turbine blade. Materials Today: Proceedings. 2018;5(2):6413-6420.

[26] Brennen CE. Cavitation and bubble dynamics. New York: Cambridge University Press; 1995.

[27] Franc JP, Michel JM. Fundamentals of cavitation. Dordrecht: Kluwer Academic Publishers; 2005.

[28] Dorji U, Ghomashchi R. Hydro turbine failure mechanisms: an overview. Engineering Failure Analysis. 2014;44:136-147. http://dx.doi.org/10.1016/j.engfailanal.2014.04.013.

[29] Lavigne S, Pougoum F, Savoie S, Martinu L, Klemberg-Sapieha JE, Schulz R. Cavitation erosion behavior of HVOF CaviTec coatings. Wear. 2017;386-387:90-98. http://dx.doi.org/10.1016/j.wear.2017.06.003.

[30] Will CR, Capra AR, Pukasiewicz AGM, Chandelier JG, Paredes RSC. Comparative study of three austenitic alloy with cobalt resistant to cavitation deposited by plasma welding. Welding International. 2012;26(2):96-103. http://dx.doi.org/10.1080/09507116.2010.527487

[31] Xiaojun Z, Procopiak LAJ, Souza NC, d'Oliveira ASCM. Phase transformation during cavitation erosion of a Co stainless steel. Materials Science and Engineering A. 2003;358(1-2):199-204. http://dx.doi.org/10.1016/S0921-5093(03)00297-1.

[32] Cruz JR, Henke SL, d'Oliveira ASCM. Effect of cold work on cavitation resistance of an austenitic stainless steel coating. Materials Research. 2016;19(5):1033-1041. http://dx.doi.org/10.1590/1980-5373-MR-2015-0442.

[33] Pukasiewicz AGM, Capra AR, Váz RF, Cortés Paredes RS, Procopiak LAJ. Liga ferrosa contendo manganês, cromo, silício e boro e com elevada resistência à cavitaçao em componente sujeito à erosao por cavitaçao o mesmo. BR Patent BR 1020160290546.2016 Dec 12.

[34] Pukasiewicz AGM, Alcover PRC Jr, Capra AR, Paredes RSC. Influence of plasma remelting on the microstructure and cavitation resistance of Arc-Sprayed Fe-Mn-Cr-Si alloy. Journal of Thermal Spray Technology. 2014;23(1-2):51-59. http://dx.doi.org/10.1007/s11666-0130001-1.

[35] Sucharski GB, Pukasiewicz AGM, Váz RF, Paredes RSC. Optimization of the deposition parameters of HVOF FeMnCrSi+Ni+B thermally sprayed coatings. Soldagem e Inspeção. 2015;20(2):238-252. http://dx.doi.org/10.1590/0104-9224/SI2002.11.

[36] Silveira LL, Sucharski GB, Pukasiewicz AGM, Paredes RSC. Influence of particle size distribution on the morphology and cavitation resistance of high-velocity oxygen fuel coatings. Journal of Thermal Spray Technology. 2018;27(4):695-709. http://dx.doi.org/10.1007/s11666-018-0708-0.

[37] Pukasiewicz AGM, de Boer HE, Sucharski GB, Vaz RF, Procopiak LAJ. The influence of HVOF spraying parameters on the microstructure, residual stress and cavitation resistance of FeMnCrSi coatings. Surface and Coatings Technology. 2017;327:158-166. http://dx.doi.org/10.1016/j.surfcoat.2017.07.073 
[38] Vaz RF, Pukasiewicz AGM, Fals HDC, Lourençato LA, Paredes RSC. Study of particle properties of different steels sprayed by Arc Spray Process. Coatings. 2020;10(4):1-13. http://dx.doi.org/10.3390/coatings10040417.

[39] Mayer AR, Bertuol K, Siqueira IBAF, Chicoski A, Váz RF, Sousa MJ, et al. Evaluation of cavitation/corrosion synergy of the Cr3C2-25NiCr coating deposited by HVOF process. Ultrasonics Sonochemistry. 2020;69:105271. http://dx.doi.org/10.1016/j.ultsonch.2020.105271.

[40] Ferreño D, Álvarez JA, Ruiz E, Méndez D, Rodríguez L, Hernández D. Failure analysis of a Pelton turbine manufactured in soft martensitic stainless steel casting. Engineering Failure Analysis. 2011;18(1):256-270. http://dx.doi.org/10.1016/j.engfailanal.2010.09.005.

[41] Behene L. Estudo da alteração de parâmetros do processo de soldagem plasma com alimentação de vareta em substrato de aço CA6NM [master dissertation]. Curitiba: Universidade Federal do Paraná; 2014.

[42] Trudel A, Sabourin M, Lévesque M, Brochu M. Fatigue crack growth in the heat affected zone of a hydraulic turbine runner weld. International Journal of Fatigue. 2014;66:39-46. http://dx.doi.org/10.1016/j.ijfatigue.2014.03.006.

[43] Lin J, Wang Z, Cheng J, Kang M, Fu X, Hong S. Effect of initial surface roughness on cavitation erosion resistance of arc-sprayed Fe-based amorphous/nanocrystalline coatings. Coatings. 2017;7(200):1-9. http://dx.doi.org/10.3390/coatings7110200.

[44] Blair M, Stevens TL. Steel casting handbook. Supplement 8: high alloy data sheets corrosion series. Materials Park: ASM International; 2004.

[45] Egusquiza M, Egusquiza E, Valentin D, Valero C, Presas A. Failure investigation of a Pelton turbine runner. Engineering Failure Analysis. 2017;81:234-244. http://dx.doi.org/10.1016/j.engfailanal.2017.06.048.

[46] Sen M, Mukherjee M, Singh SK, Pal TK. Effect of double-pulsed gas metal arc welding (DP-GMAW) process variables on microstructural constituents and hardness of low carbon steel weld deposits. Journal of Manufacturing Processes. 2018;31:424-439. http://dx.doi.org/10.1016/j.jmapro.2017.12.003.

[47] Pukasiewicz AGM, Oliveira FR, Capra AR, Paredes RSC. Influência da refusão por plasma na microestrutura de um revestimento Fe-MnCr-Si depositado por aspersão térmica arco elétrico sobre aço inoxidável ASTM A743-CA6NM. Soldagem e Inspeção. 2012;17(1):65-75. http://dx.doi.org/10.1590/S0104-92242012000100010.

[48] Wube Dametew A. Experimental investigation on weld ability of cast iron. Science Discovery. 2015;3(6):71-75. http://dx.doi.org/10.11648/j.sd.20150306.15

[49] Pukasiewicz AGM, Pukasiewicz AGM, Vaz R, Araújo IB. Corrosion resistance of iron-based alloy coatings deposited by HVOF process. In: ITSC 2019 - Proceedings of the International Thermal Spray Conference; 2019; Yokohama. Materials Park: ASM International; 2019. p. 359-368.

[50] Arndt REA, Ippen AT. Rough surface effects on cavitation inception. Journal of Fluids Engineering, Transactions of the ASME. 1968;90(2):249-261.

[51] Pukasiewicz AGM. Desenvolvimento de revestimentos Fe-Mn-Cr-Si-Ni resistentes à cavitação depositadas por aspersão ASP [doctor thesis]. Curitiba: Universidade Federal do Paraná; 2008.

[52] Pukasiewicz AGM, Capra AR, Vaz RF. Cavitation resistance of ASP coatings, ultrasonic testings and Francis runner field performance comparison. In: Materials Science and Technology Conference and Exhibition 2013, MS\&T 2013; 2013; Montreal. Westerville: The American Ceramic Society; 2013. p. 799-805.

[53] Silveira LL, Pukasiewicz AGM, Aguiar DJM, Zara AJ, Björklund S. Study of the corrosion and cavitation resistance of HVOF and HVAF FeCrMnSiNi and FeCrMnSiB coatings. Surface and Coatings Technology. 2019;374:910-922. http://dx.doi.org/10.1016/j.surfcoat.2019.06.076. 